stance (anterior loba) increased the egg production of hens whose production curve was on the decline: Case 1, with 35 hens in isolated pens; Case 2, with 655 hens.
"2. The dosage was effective on the fourth day after the first dose and lasted for several days after the last dose.

" 3 . The hatchability of eggs from dosed parents was increased."

\title{
Heredity and Criminal Delinquency
}

Heredity is considered only a minor cause of delinquency by William Healy, director of the Juvenile Psychopathic Institute of Chicago, who presents an analysis of 823 individual cases in his recent book "The Individual Delinquent." Mental abnormalities and peculiarities appear as a main factor 455 times and as a minor factor 135 times; but Dr. Healy apparently does not consider such abnormalities to be the equivalent of bad heredity. "Defects of heredity" are noted in no case as a main factor, but in 502 cases as a minor factor. Other causes listed by Dr. Healy, such as "abnormal physical conditions," "defective home conditions, including alcoholism," would be thought by many students to be largely due to defective heredity; and to heredity, therefore, might well be ascribed a much more important role in the production of criminal delinquents, than Dr. Healy gives to it, if one used the same facts but started with a different viewpoint or different definitions.

\section{An Outline of Eugenics}

Being Well-Born, by Michael F. Guyer, Professor of Zoology at the University of Wisconsin. Pp. 374, price $\$ 1.00$. Childhood and Youth Series. Indianapolis, Bobbs-Merrill Company, 1916.

The field of heredity in man is resurveyed by Dr. Guyer in a compact volume which omits few topics of importance. The study of the cell and the mechanism of heredity are given much space, and methods of cutting off defective lines of descent are also dealt with at length. Less attention is given to constructive eugenics than one might wish, but the recommendations made are sound and conservative. A full glossary adds to the value of the volume. In the highly controversial field of Mendelism the author's conclusions will not always be accepted by other students, but this is a detail which detracts little from the general soundness of judgment shown. A comparison of Dr. Guyer's book with those on similar subjects by other authors will convince anyone that there is substantial agreement between those who have studied the problem from various angles, in regard to what eugenics can and cannot do.

\section{Eugenics in Hungary}

An organization for Race-Hygiene (Eugenies) exists in Hungary since two years. Instead of founding a new society, existing societies prominent in social and medical work organized a common Committee for Race-Hygiene in Budapest, on February 25, 1914 , under the leadership of Count Paul Teleky and Professor Apathy. There is no special organ for publications as yet, but the Hungarian Sociological Review has a permanent column for topics of Race-Hygiene. The work was started with the government taking much interest in it, when the war broke out and stopped further activities except an action to repress venereal diseases in the army.

G. von Hoffman, Berlin. 